\title{
Politeness strategy preference of male and female teachers in classroom interaction during English classes
}

\author{
Lestari, I Gusti Ayu Agung Yuni ${ }^{1}$, Seken, Ketut and Putra, I Nyoman Adi Jaya \\ Universitas Pendidikan Ganesha
}

\begin{abstract}
Politeness is the use of right word or phrase in the proper context, which is determined by the rules that are prevalent in society. This study aimed to identify the politeness strategies used by male and female teachers; and analyze the differences in terms of strategies used by teachers. This study was designed in the form of qualitative research. The data were taken from observed interactions between teachers and students during English classes and interviewed the teachers of SMPN 2 Abiansemal. The obtained data were in form of utterances produced in teaching learning process during English classes. The utterances were identified and analyzed descriptively by using [9]'s theory in order to know the politeness strategy used by male and female teachers. The result of this study showed that male and female teacher implied four types of politeness strategies, namely; bald on record, positive politeness, negative politeness, off-record; male and female teachers were different on strategy preference depended on context and situation.
\end{abstract}

Key Words: Politeness Strategies, Gender, Classroom Interactions

\section{Introduction}

Politeness is a common social phenomenon, and regarded as a moral code in human communication and social activities. It is one of the basics of human interaction. Many researchers such as $[4,9,10]$ focused on politeness in their studies and proposed different theories about politeness. Just like any other interaction, teacher-student interaction is positively affected by politeness. It is important to know about the extent in how teachers apply politeness strategies to their language use in EFL classroom. EFL context is a special place where nonnative language is used more frequently. The higher students' overall level 
of English proficiency, the better students can understand teachers' talk, and the higher awareness students may have in teachers' politeness strategy. Considering by the politeness strategy used in classroom and difference gender explained, it reflects that discussing politeness as strategy used by the speaker is also important in classroom interaction. Politeness strategy can be used as politeness behavior to the students by the teacher or vice versa as the function of the politeness strategy is to maintain a good relationship of to save hearer's face. Usually, the teacher wants to save the students' face in order to make a meaningful teaching learning process and keep the students pay their attention. In addition, SMP Negeri 2 Abiansemal is one of junior high schools in Abiansemal sub district that taught English as a foreign language. This school is located between city and village that affects the way teachers and students behave, think and communicate. The location of this school is good because it is in transition position which is not in a city and inland neither. In addition, it is also important to know the differences of politeness strategy preference by male teacher and female teacher. The teachers come from different background and they have different experience as well, and those influence the politeness strategies preference by the teachers. Men and women differ psychologically in the way they act, from the style in which they communicate [1].This study aims to identify politeness strategies used by male and female teachers and to analyze the differences in terms of politeness strategies used by male and female teachers of SMP Negeri 2 Abiansemal. This present study used [9]'s politeness theory as the main theory to analyze types of politeness strategy used by male teacher and female teacher. This theory was one of popular theories in politeness strategies. They state that politeness is the speaker's strategy to minimize the effect of an FTA (Face Threatening Act) in communication. [9] Sum up human politeness behaviour in four main types of politeness strategies: positive politeness, negative politeness, bald on record, and off-record-indirect strategy. According to [9], positive politeness consist of 15 sub strategies: notice, exaggerate, intensify interest to hearer, use in-group identity markers, seek agreement, avoid disagreement, presuppose common background, joke, assert speaker's knowledge of and concern for hearer's wants, off or promise, be optimistic, include both speaker and hearer, give or ask for a reason, assume or assert reciprocity and give gift to hearer. According to [9] there are ten strategies include negative politeness: be conventionally indirect, question/ hedge, be pessimistic, minimize the imposition, give deference, apologies, impersonalize $\mathrm{S}$ and $\mathrm{H}$, state the FTA as a general rule, nominalize, and go on record as inquiring a debt or as not indebting $\mathrm{H}$. These strategies presume that the speaker will be imposing on the listener and there is a higher potential for awkwardness or embarrassment than in bald on record strategies and positive politeness strategies. Negative face is the desire to remain autonomous so the speaker is more active to include an out for the listener, through distancing styles like apologies. Bald on-record strategies usually do not attempt to minimize the threat to the hearer's face, although there are ways that bald on-record politeness can be used in trying to minimize face-threatening acts implicitly. Often using such a strategy will shock or embarrass the addressee, and so this strategy is most often utilized in situations where the speaker has a close relationship with the audience, such as family or close friends. Moreover, [9] defined the criteria of bald onrecord as; the one who speak directly in emergence situation, with maximum efficiency, and usually be used to talk with someone you know well. The fourth strategy is off record. Off record utterance is usually something general (containing less information in the sense that it rules out fewer possible states of affairs) of actually different from what it is really meant. There are15 sub-strategies conveying off record: give hints, give association clues, presuppose, understate, overstate, use tautologies, use contradiction, be ironic, use metaphor, use rhetorical question, be ambiguous, be vague, over generalize, displace $H$, and be incomplete. 


\section{Research Method}

The study was designed in qualitative research. This type of research was chosen because it aimed at describing a situation or phenomena. The term qualitative research referred to research that was based on description data that do not use of statistical procedures. Observation and interview were used for data collection. The subjects of the study were a male English teacher and a female English teacher of SMP Negeri 2 Abiansemal. The interaction between teachers and students were observed and video-recorded for two hours of class. After the observation, the researcher transferred the data from video into transcriptions in order to make the analysis easier and clear. The data analysis was done after making the transcriptions by categorizing the teachers' utterances based on politeness strategy by [9]'s theory. After the data were taken from the result of transcription, observation and interview, then the data were analyzed by using the three steps of data analysis by [8]. Those three steps were: First was data reduction, in this step the researcher scrutinized, selected, and simplified politeness strategies used by male and female teacher during English classes in junior high school from super strategies to sub strategies. Next step, the teachers' utterances were evaluated by using [9]'s politeness theory. Second, data display which in this step the researcher putted the data into table, matrix and pie chart then the data interpreted based on the display to make the readers understand the result of the study easier. Third, conclusion drawing or verification was not a one-blow process and did not necessarily take place just at the end on an episode of the data analysis. It was drawn base on the interpretation of the data, interview and observation notes. This present study concluded the important data to be used to answer the research questions.

\section{Results}

This present study found that there were some politeness strategies found to be employed at English classroom interaction in SMP N 2 Abiansemal. The data were collected by conducting observation in four classes which were handled by two teachers. After collecting the data, the researcher classified the data based on the [8]'s theory. The data showed that 90 (36.14\%) expressions were classified as Bald-on record, 93 (37.35\%) were classified as positive politeness, $56(22.49 \%)$ were classified as negative politeness, and 10 $(4.02 \%)$ were classified as bald-off record. The findings of this study showed some differences of strategy used by the male and female teacher in teaching learning process in class interaction. Those differences came out because of some reasons such as the distance of their relationship and teacher's confidence. This result was strengthen by another study from [7] showed that evidently the adoption of politeness strategies shortens the teacherstudents social distance, makes the class interesting, and in turn facilitates English teaching and learning. In addition, as [5] in his research stated that there are three parameters which influence the chosen of politeness strategy, those are: social distance, power, and imposition. In addition, context of situation influenced the differences politeness strategies used by teachers. As [2] produced a model for analysis of speech event: setting and scene, participants, ends, act sequence, key, instrumentalities, norms, genres. Besides, the differences of politeness strategy used by male and female teacher happened because there was indication of linguistics' strategy stated that men and women's communication style different. Psychologically, men and women are different in the way they act such as from the style in which they communicate to the way in which they attempt to influence others. On the other hand, [3] showed that while men view conversations as a way of establishing and maintaining status and dominance in relationship. Male teacher used bald on record as the dominant politeness strategy especially to give command or instruction. 


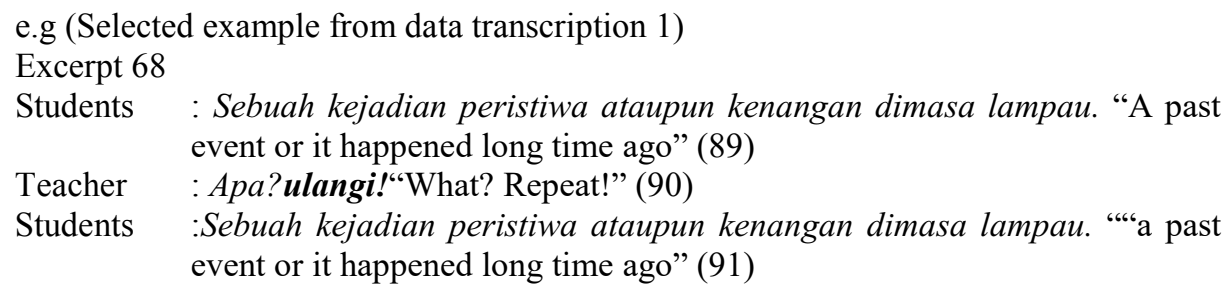

The excerpt 68 above showed that male teacher used his superiority in the interaction. The command was direct and clear to get all students did what the teacher wanted. Men are goal oriented [6]. Male teacher defined his sense of self through his ability to achieve result. Besides, female teacher used positive politeness strategy as the dominant strategy during classroom interaction because she wanted to show her solidarity in the interaction. In addition, female teacher sees the purpose of conversation to create and foster an intimate bond with the other party by talking about topical problems and issues they are communally facing [3].

e.g (Selected example from data transcription 3)

\section{Excerpt 35}

$\begin{array}{ll}\text { Teacher } & \text { :Merek aapa? "They what?" (571) } \\ \text { Students } & \begin{array}{l}\text { :Mereka suka berenang! (lebih keras) “They like } \\ \text { swimming”(louder)(572) }\end{array}\end{array}$

Teacher :Iya. Ada yang suka berenang disini? "Yes. Is there anyone like swimming here?" (573)

Student : Nggak. "No"(574)

The expression on excerpt 35 intensified interest to $\mathrm{H}$ by asking about their likes especially about swimming. In this case, teacher's interest to students' interest which related with the lesson at that time about like and dislike. Asking students' interest gave positive impression to teacher that could lift up teacher-students relationship. Women are relationship oriented [6]. Female teacher defined her sense of self by her feelings and by the quality of their relationships.

\section{Conclusion}

This research was investigating and analyzing kinds of politeness strategy used by male and female English teachers during English classes at SMP Negeri 2 Abiansemal in academic year 2016/2017. The researcher examined and analyzed the politeness strategies used by the teachers in relation to their effort to manage the relationship between the teachers and the students. The result of this study showed that female teacher use positive politeness as dominant strategy, and followed by bald on record, negative politeness, off record. Besides for male teacher use bald on record as dominant strategy and followed by positive politeness, negative politeness, off record. The differences in politeness strategies preferences were performed by some motives from the teachers when it was seen by the similar context. Similar context or situation of the teachers could employ different strategies used of male and female teacher. The context or situation referenced to some motives. Those motives were found based on observation and interview with the teachers. Besides, the differences of politeness strategy used by male and female teacher because 
there was indication because of linguistics' strategy stated that men and women's communication style different. Men and women differ psychologically in the way they act such as from the style in which they communicate to the way in which they attempt to influence others.

\section{References}

1. A. Sulu, Teacher's Politeness in EFL Class, 2, 216-221 (2015)

2. D. Hymes,Foundation in Sociolinguistics: An Ethnographic Approach (Philadelphia. University of Pennsylvania Press, 1974)

3. D. Tennen, You Just Don't Understand: Women and Men in Conversation (Ballantine Books, New York, 1990)

4. G. Leech, Principle of Pragmatics (London: Longman, 1995)

5. I K. Seken, Kesantunan Linguistik dan Pembelajaran Bahasa Kedua Naskah Orasi Pengenalan Jabatan Guru Besar Tetap Dalam Bidang Pendidikan Bahasa Inggris. (Singaraja: Ganesha University of Education, 2007)

6. J. Grey,Men are from Mars, Women are from Venus:a Practical Guide for Improving Communication and Getting What You Want in a Relationship (HarperCollins, New York, 1992)

7. L. Peng, F. Xie, Cai. A Case Study of College Teacher's Politeness Strategy in EFL Classroom. Theory and Practice in Language Studies, 4 (2014)

8. M. B. Miles, A. Huberman, Qualitative Data Analysis: an Expanded Sourcebook (2nd. Ed.) (London: Sage, 1994)

9. P. Brown, S. C. Levinson, Politeness: Some Universals in Language Usage.(Cambridge: Cambridge University Press, 1987)

10. R. Lakoff, The Logic of Politeness: or Minding your p's and q's. (Chicago: Linguistics Society, 1975) 